\title{
Analysis Of Shoe Manufacturing Factory By Simulation Of Production Processes
}

\author{
Muhammed Selman ERYILMAZa \\ Ali Osman KUŞAKCI ${ }^{b}$ \\ Haris GAVRANOVICc \\ Fehim FINDIK ${ }^{\mathrm{d}}$ \\ ${ }^{a}$ Graduate of Department of Industrial Engineering, International University of Sarajevo, \\ Sarajevo, Bosnia Herzegovina, \\ mselive@gmail.com \\ ${ }^{b}$ Department of Industrial Engineering, International University of Sarajevo, Sarajevo, Bosnia \\ Herzegovina, \\ akusakci@ius.edu.ba \\ ${ }^{c}$ Department of Industrial Engineering, International University of Sarajevo, Sarajevo, Bosnia \\ Herzegovina, \\ haris.gavronovic@gmail.com \\ ${ }^{d}$ Department of Industrial Engineering, International University of Sarajevo, Sarajevo, Bosnia \\ Herzegovina, \\ ffindik@ius.edu.ba
}

\begin{abstract}
In this study, shoe manufacturing is analyzed and specific production policy is developed for the men's shoe making company. The main characteristic of the shoe manufacturing is that the daily production rate and processing times are highly volatile and subject to high variances depending on the model and rapidly changing trends. The aim of this study is to determine the optimum production policy over the combinations of the models which will be produced in daily working schedule. A simulation study was developed to see at what degree the variations of the models effect the throughput rate.
\end{abstract}

Key words: Shoe Manufacturing, Production Analysis, Simulation, Arena.

\section{Introduction}

The customized products such as footwear or clothing industry where customer's taste and choices change rapidly according to fashion dictates are known as labor-intensive products. Shoe making is neither an easy production system nor a simple business. It requires high skill and a lot of diverse knowledge in many aspects that may affect the quality, the appearance and the functions of a shoe. The significant thing is that it requires a lot of work which makes shoe making as a typical labor-intensive process. 
Under the major goal of this study, the production analysis of the shoe manufacturing is recognized as a highly important stage to understand the characteristics of the production system and to assess its behavior under alternative policies. Production and process analysis are significant for the manufacturing companies to improve their productivity and to optimize usage of the resources. It is obvious that, manufacturing is a complicated system that involves sets of tasks, materials, resources, products, and information. By doing production analysis, there are advantages of understanding the way the production is done, finding the problems and the gapping between current performance and expected targets.

The production analysis discussed in this study is mainly concerned with shoe manufacturing facility in terms of the effect of the model variations on throughput rate and usage of resources. The selected production system for this study by considering the characteristic of the production is the cellular manufacturing. It is characterized in production facility where production units which have the medium production quantity and product variety are commonly possible to make production in cells or batches (Groover, 2007). Because each same style of shoes are grouped with the different sizes in a batch. So, it also brings the group technology under the frame cellular manufacturing system.

In the shoe manufacturing, the production line is dynamic, discrete and stochastic. Its randomness is due to variable processing times, as well as random failures and subsequent repairs. Such randomness makes it difficult to control the production process or to predict their behavior (Altiok \& Melamed, 2007). A simulation model which is established to understand and to analyze the structure of manufacturing reveals relationships among the processes and provides to determine the impact on the throughput of the production.

The main objective of the thesis is to measure the effect of variable styles (models) on the output of a production line. Because the daily production rate and processing times are variable depending on the model, the simulation model will provide a sensitivity analysis of the efficiency on the throughput rate and resource utilization.

This study will be based on the simulation modeling of the men's shoe manufacturing. After experimentation of simulation model, the results will be analyzed to carry out the main objectives of the production system

\section{Simulation}

The term "Simulation" refers to a broad collection of methods and applications to mimic the behavior of real systems (Kelton, et al., 2010). This is normally performed by developing a simulation model on a computer with appropriate software.

A simulation model takes the form of a set of assumptions about the operation of the system, expressed as mathematical or logical relations between the objects of interest in the system (Winston, 2004). Simulation models enable us to evaluate alternative system designs and operating procedures in a convenient way when optimization models are not practical. Testing alternatives on a real production system is usually too expensive and time consuming. Therefore, simulation enables us to do this testing and evaluation in a fast, cheap and safe manner.

There are several steps that must be followed to carry out a simulation study. 
These steps will be used to build out simulation modeling of the shoe manufacturing company. The steps in a simulation study (Winston, 2004) are shown in Figure 2. However, in some studies these several distinct stages may not be included; there can even be some overlap between some of the stages.

\section{Shoe Manufacturing}

Figure 1: Process diagram for finished shoes

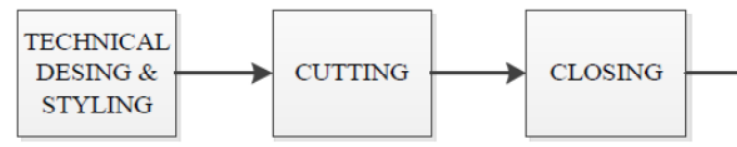

Figure 2: Steps in a Simulation Study

Shoe manufacturing is most likely laborintensive process and it cannot be fully automated. It requires craftsmanship in each phase of the production. More than a hundred operations are required for making a pair of shoes. With the development of the footwear machines, the production time has been reduced and processes are performed separately. Depending on the type of shoes and material usage, the manufacturing process can vary.

The footwear company has mainly five departments in which a progressive route is followed in order to produce the final product. These are; Technical Design and Styling, Cutting Department, Closing Department, Lasting \& Making Department, and Finishing Department as depicted in Figure 1.

\section{Methodology}

In order to carry out the simulation study successfully, the structured processes must be followed. These are:

- Problem Formulation and Solution Methodology

System and Simulation

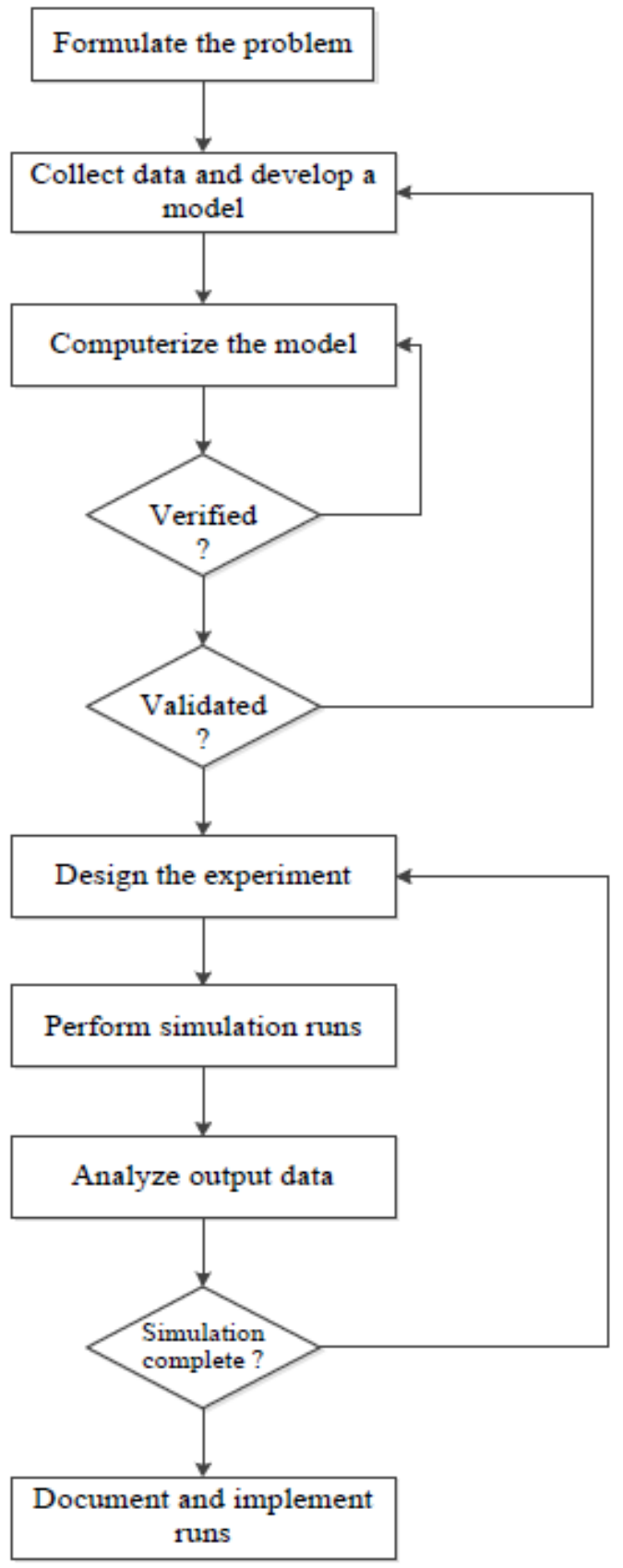

(Source: Winston, 2004, p.1185)

- Specifications

- Data Collection

- Model Construction

- Verification 
- Validation

- Experimentation and Analysis

- Presenting the Results and

\section{Conclusions}

Hereby, these processes will be analyzed respectively.

\section{Problem Formulation and Solution Methodology}

The main constrains and assumptions which cause having problems in the production plant can be determined as follow;

- Daily production schedule consist of variety of the models by given orders,

- Daily production contains at least 4 different type models and maximum 10 ,

- Some work stations have lofrg processing time to finish an entity,

- Processing times differs related to different type of models,

- Combination of different model $\mathrm{s}_{3}$ cause to reduce of production 4 rate.

- There is no way to produce single ${ }_{6}^{5}$ model in a day.

The main problem which arises from 8 given reasons is having variety of models in a same day. Namely, if the daily production consists of 10 models, 1 the production rate is decreasing whe 2 Finishing it is compared with the minimflaw Time

variety. The complexity of production causes also having excessive usage of resources.

Having established initial boundaries which are stated as a problem; the required performance measures, which look appropriate to the situation, were considered:

- The daily production rate (depending on the varieties of the
Table 1: Time analysis of the shoe manufacturing

To determine the specific solution methodology, the parameter should be based on a question of "which will most likely give the most cost-effective solution" (Kelton \& Sadowski, 2004).

E ANALYSIS FOR MODEL : 359 DAY:1

E ANALYSIS FOR MODEL : 359 DAY: 1

models)

- Mean resource utilization (measured as the per machine utilization)

- The flow time (completion time of a shoes)

- Queue waiting time and number of waiting in processes

- Number of reworks.

Work Time ng ssing Time

Preparation ers

$\begin{array}{llllll}\text { Preparation } & 1 & 0,5 & 0 & 1 & 1,5 \\ \text { Coupling } & & & & \end{array}$

$\begin{array}{llllll}\text { Toe-Puff } & 1 & 0,75 & 0,58 & 0,133 & 1,463\end{array}$

$\begin{array}{llllll}\text { Back Part } & & & & & \\ \text { Molding } & 1 & 0,16 & 0,5 & 0,166 & 0,826\end{array}$

$\begin{array}{llllll}\text { Insole } & 1 & 0,25 & 0,25 & 0,55 & 1,05\end{array}$

Roughing

$\begin{array}{llllll}\text { up } & 1 & 0,16 & 0,1 & 0,33 & 0,59\end{array}$

$\begin{array}{llllll}\text { Toe Lasting } & 1 & 0,5 & 0,16 & 0,7 & 1,36\end{array}$

Heel/Side

$\begin{array}{llllll}\text { Lasting } & 1 & 1,6 & 0,13 & 0,083 & 1,813\end{array}$

$\begin{array}{llllll}\text { Ironing } & 1 & 0,5 & 0 & 2 & 2,5\end{array}$

Scouring/

$\begin{array}{llllll}\text { Roughing } & 2 & 0,78 & 0,25 & 1,5 & 2,53\end{array}$

$\begin{array}{lllllr}\text { Gluing } & 1 & 0,6 & 2 & 1,4 & 4\end{array}$

$\begin{array}{llllll}\text { Attaching } & 2 & 0,1 & 0,625 & 0,5 & 1,225\end{array}$

- 4

0,25

0,25

2,5 21,857
Table 2: Process time analysis per different models in a day

\begin{tabular}{lrrrrr}
\hline Processes & 612 & 019 & 013 & 015 & 846 \\
\hline $\begin{array}{l}\text { Preparatio } \\
\mathrm{n}\end{array}$ & 1,6 & 1,1 & 1,5 & 1,3 & 1,1 \\
\hline
\end{tabular}




\begin{tabular}{|c|c|c|c|c|c|}
\hline \multicolumn{6}{|l|}{ Coupling } \\
\hline $\begin{array}{l}\text { Toe-Puff } \\
\text { Back Part }\end{array}$ & 1,466 & 1,466 & 1,466 & 1,466 & 1,466 \\
\hline $\begin{array}{l}\text { Molding } \\
\text { Insole }\end{array}$ & 0,9 & 0,8 & 0,7 & 0,8 & 0,8 \\
\hline $\begin{array}{l}\text { Tacking } \\
\text { Roughing }\end{array}$ & 1,03 & 1,03 & 1,03 & 1,03 & 1,03 \\
\hline & 0,5 & 0,5 & 0,5 & 0,5 & 0,5 \\
\hline $\begin{array}{l}\text { Lasting } \\
\text { Heel / Side }\end{array}$ & 1,3 & 0,8 & 0,9 & 1,1 & 1,2 \\
\hline Lasting & 1,816 & 1,816 & 1,816 & 1,816 & 1,816 \\
\hline $\begin{array}{l}\text { Ironing } \\
\text { Scouring / }\end{array}$ & 2,2 & 2,2 & 2,1 & 2,2 & 2,1 \\
\hline Roughing & 2,5 & 2,1 & 2 & 2,3 & 2,3 \\
\hline Gluing & 4,9 & 4 & 4,9 & 4,2 & 4,8 \\
\hline Attaching & 1,225 & 1,225 & 1,225 & 1,225 & 1,225 \\
\hline Finishing & 2,6 & 2,9 & 2,15 & 2,75 & 2,85 \\
\hline TOTAL & $\begin{array}{c}22,03 \\
7\end{array}$ & $\begin{array}{c}19,93 \\
7\end{array}$ & $\begin{array}{c}20,28 \\
7\end{array}$ & $\begin{array}{c}20,68 \\
7\end{array}$ & $\begin{array}{c}21,18 \\
7\end{array}$ \\
\hline
\end{tabular}

The production line modeled has 12 workstations, each composed of one place. Each simulation run represented one working day $(9$ h). Each daily production plan was composed about 250 pairs as the uppers.

At the end of the day, the average production is around 170 pairs in the shoe making factory. For each pair of shoes same amount of time are performed, all of the uppers must pass the all workstations one by one. All of the operations are performed as linear sequence. The characteristic of the shoe production plan is identified in following circumstances;

- All of the required operations are common for all type of models,

- For each type of model and variation size of different models create different process times,

- At the beginning of the production namely in the preparation workstation 250 pairs of uppers are become ready at $\mathrm{t}=0$,

- As the production continues, there can be some reworks due to wrong lasting operation or some scraps which occurs from the raw material after the toe lasting. The rate of reworks measured from the factory is around $5 \%$. The defected shoes are resent to preparation operation,
- Data collected are measured for per pair of shoes in each work station.

- The data collected changes randomly for each pair of shoes.

- Each batch contains 10 pairs of one single model of shoes with variable sizes.

The analysis of the production rate is performed for 7 different type of production schedule. Namely, the analysis for all performance criteria covers the 7 days of production data. The minimum number of models produced is 4 and the maximum number of the models is 10 . The simulation model for this study is first experimented with the daily production rate. For each daily working period, the quantity of production changes due to the varieties of the models and processing times.

Figure 3: Arena simulation model for the Men's shoe manufacturing factory

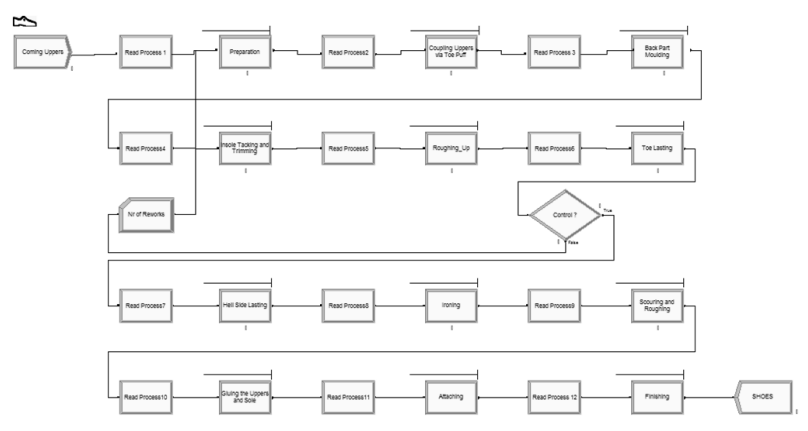

Table 3: Results summary for the daily production rate

\begin{tabular}{|l|l|l|l|}
\hline $\begin{array}{l}\text { Variety } \\
\text { (models }\end{array}$ & $\begin{array}{l}\text { Quantit } \\
\text { y }\end{array}$ & $\begin{array}{l}\text { Conversio } \\
\mathrm{n}\end{array}$ & $\begin{array}{l}\% \\
\text { Chang }\end{array}$ \\
\hline
\end{tabular}




\begin{tabular}{|c|c|l|l|}
\hline ) & & & $\mathrm{e}$ \\
\hline 4 & 130 & 220 & \\
\hline 5 & 129 & 218 & $-0,007$ \\
\hline 6 & 124 & 210 & $-0,046$ \\
\hline 7 & 120 & 203 & $-0,076$ \\
\hline 8 & 118 & 200 & $-0,092$ \\
\hline 9 & 108 & 183 & $-0,169$ \\
\hline 10 & 107 & 181 & $-0,176$ \\
\hline $\begin{array}{c}\text { Total } \\
\text { Avg. } \\
\text { Prod }\end{array}$ & 120 & & \\
\hline
\end{tabular}

The least production is 107 made by producing 10 different models. The production rate has reduced by $17 \%$. The average number of production is reached by producing 118 pairs with 8 different models. The changes of the daily production rate by the variety of the model are also depicted in Figure 6.

Figure 4: Changes of the daily production rate by the variety of the model

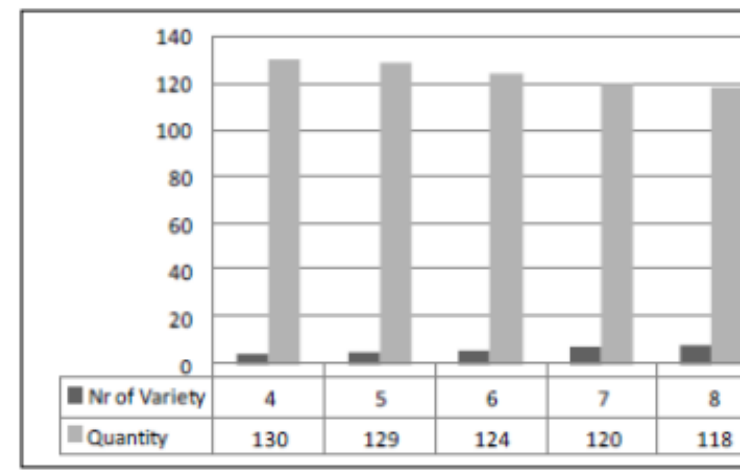

In each workstation, as the number of different models of shoes increase the process time increases as well. The second important thing is, the process time of the "Gluing the uppers and sole" rises rapidly due to long duration of the process. This is can be called as "Bottleneck Station" which mean the longest process time between the workstation.

Figure 5: Process times of the variations in each workstation

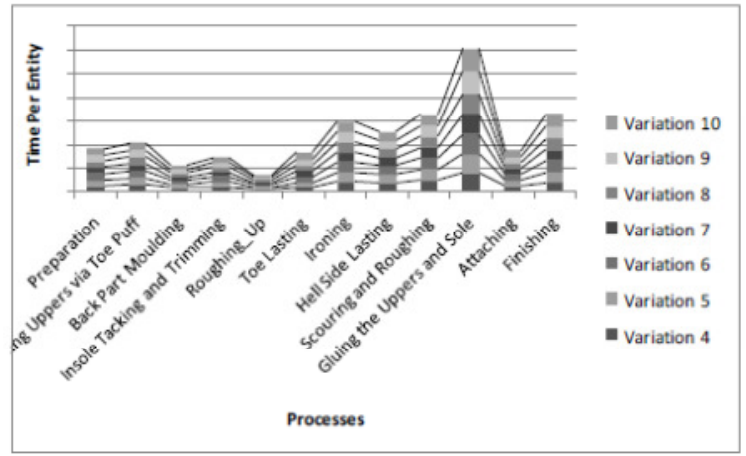

Figure 6: Total average waiting times and number of waiting uppers in queue

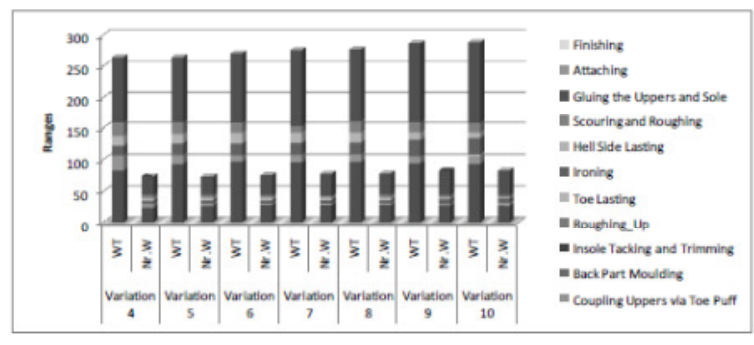

When the number of different models of shoes or varieties increases the waiting time of the next job becomes high. So the queue length has also increased. By producing of four different models of shoes wait $105.89 \mathrm{~min}$ in the bottleneck stations which is the gluing of the upper and sole. The quantity of waiting jobs is 29 pairs in average. In the case of working with maximum variety, the waiting time increased $23 \%$ and the number of waiting jobs has increased around 35\%. Although this ratio, in some workstations both waiting time and number of waiting jobs are 0 . It directly seized and released by the workstation.

Table 4: Result summary of average reworks

\begin{tabular}{lllll}
\hline Count & $\begin{array}{l}\text { Aver } \\
\cdot\end{array}$ & $\begin{array}{l}\text { Half } \\
\text { Widt } \\
\text { h }\end{array}$ & $\begin{array}{l}\text { Min } \\
\text { averag } \\
\text { e }\end{array}$ & $\begin{array}{l}\text { Max } \\
\text { averag } \\
\text { e }\end{array}$ \\
\hline $\begin{array}{l}\text { Rework } \\
\text { s }\end{array}$ & $\begin{array}{l}8.90 \\
0\end{array}$ & 2.25 & 5.000 & 16.000 \\
\hline
\end{tabular}

The results obtained by the experimentation of the model represent that the minimum number of defect after the 10 replications is 5 pairs of lasted uppers. 
And the maximum defective ones are 16 pairs of lasted uppers.

\section{Conclusion}

The first performance criteria were the analysis of the daily production rate. The presented analysis showed that the highest production is obtained by producing 4 different types of models. The production rate was 130 pairs of shoes after the experimentation and when it is converted to the real case 220 pairs of shoes might be produced using this policy. The average production or the breakaway point occurs by the producing 8 models. The quantity was 118 pairs of shoes in simulation and 200 pairs in fact. So, there is around 9\% decreasing if the productions run with the 10 different models. If we substitute this to the 10 days of production, the production rate might increase around 200 pairs by producing 4 models. Namely working with 4 different models increases the production rate.

The second performance criteria were the analysis of the flow time. This was applied by two types of time measurements; flow time and cycle time. When we look at the flow time the production has not been affected by the variations. It slightly differs and because of bottleneck station. The second thing is the cycle time which is the total duration of the all processes to finish a pair of shoes. The Figure 9 is analyzed the total average time per shoes concludes that the increasing number variations in the production has effect on the time of the completion of the processes.

Figure 7: Average cycle time for each variation

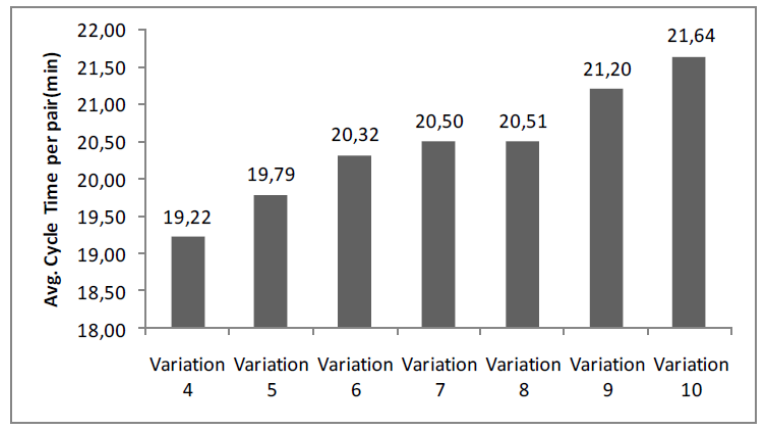

Thirdly, the analyzed performance criteria were the analysis of the queue. As the Figure 8 represents, the waiting time and the number of waiting jobs in the queue of the workstation increases as the variety of the model. Within this queue, the longest waiting time occurs at the bottleneck station which is obviously "gluing the uppers and sole". This bottleneck which causes the more waiting time can be eliminated by adding additional resources.

The forth criteria was the analysis of the resource utilizations. The results showed that whatever the amount of variation is, resource loadings are almost same for each process. The prominent thing is again on the bottleneck station. Like in queue case, if the additional resource can be added, the utilization will be more efficient and the productivity will be also affected in same manner.

The last performance criteria were the analysis of the reworks. Because the defective rate of the lasted uppers behaves at steady-rate, the average amounts of reworks are 9 pairs of shoes. The minimum defective rate is 5 pairs and the maximum average amount of defects is 16 pairs. This result both shows the validation of the study and the same results based on the real factory. If the production policy is made to run with 4 different types of models or variations in one day, the productivity will increase by almost $10 \%$. Even if this ratio seems a bit less, the influence within the production is high. 
There is an indication of improvement in the bottleneck station which is the "gluing uppers and sole". Because the queue waiting time and number of waiting units is too high, there should be additional resources in this workstation to reduce the operation and waiting time.

Finally, by looking these results an observation is figured out that the shoe manufacturing process regularly encompasses a sequence of operations which is common to most models. Concerning this fact, if the production performs with the 4 different types of models in each day, the production will be increase and the cost of the operations will be reduced. The new production policy should be adjusted in that way. Nevertheless, the attention should be given to the assessments on the effects of the changes in input variables based on the company's alternative operating policy.

\section{References}

[1] Altiok, T., \& Melamed, B., 2007. Simulation Modeling and Analysis with Arena. California (USA): Elsevier. [2] Ceroni, J.A., \& Nof, S.Y., 2005. Task parallelism in distributed supply organizations: a case study in the shoe industry. Production Planning \& Control, 16(5), pp.500-513

[3] Costa, M.T., \& Ferreira, J.S., 1999. A simulation analysis of sequencing rules in a flexible flow line. European Journal of Operational Research, 99(119), pp.440-450

[4] Greasley, A., 2008. Enabling a Simulation Capability in the Organization. London (UK): Springer. [5] Groover, Mikell P., 2007. Work Systems and the Methods, Measurement, and Management of Work. Upper Saddle River (NJ): Pearson Education. [6] Hillier, F.S. Lieberman, G.J., 2005. Introduction to Operations Research. 8th ed. Singapore: McGraw-Hill.
[7] Joseph, S. Martinich., 1997.

Production and operations Management: an applied modern approach. Canada: John Wiley \& Sons.

[8] Kelton, W.D., \& Sadowski, R.P., \& Sadowski, D.A., 2004. Simulation with ARENA. 2nd ed. New York: McGrawHill.

[9] Kelton, W.D., \& Sadowski, R.P., \& Swets, N.B., 2010. Simulation with ARENA. 5th ed. New York: McGrawHill.

[10] Kumar, S.A. Suresh, N., 2006. Production and Operations

Management. New Delhi: New Age Int. [11] Nahmias, S., 2009. Production and Operations Analysis, 6th ed. New York: McGraw-Hill.

[12] Nisanci, H.I., \& Sury, R.J., 1980. Production analysis by simulation in a shoe manufacturing factory. Internal Journal of Production Research, 18(1), pp. 31-41.

[13] Nisanci, H.I., Sury, R.J., 1981. An application of group technology concepts in shoe manufacturing. Internal Journal of Production Research, 19(3), pp. 267275.

[14] Subramanian, A.K., 2004. Cell loading and scheduling in a shoe manufacturing company. Ohio University (MS). [Online] Available at: http://etd.ohiolink.edu/view.cgi?acc_num =ohiou1108477506 [Accessed: 2 March 2011]

[15] Winston, W.L., \& Goldberg, J.B., 2004. Operations Research: applications and algorithms. 4th ed. USA: Thomson Learning.

[16] Zangiacomi, A., \& Zhijian, L.S., \& Boer, C.L., 2004. Process planning and scheduling for mass customised shoe manufacturing. Internal Journal of Computer Integrated

Manufacturing,17(7), pp.613-621.

[17] Zangiacomi, A. et al, 2004. Process planning and scheduling for mass customised shoe manufacturing. Int. J. Computer Integrated Manufacturing, 17(7), pp.613-621. 